\title{
PENGARUH PEMAHAMAN AGAMA ISLAM TERHADAP ETIKA BERPAKAIAN
}

\author{
Rita Oktaviani ${ }^{1}$, Retno Triwoelandari ${ }^{2}$, Ikhwan Hamdani ${ }^{3}$ \\ 1,2,3 Program Studi Pendidikan Agama Islam, Universitas Ibn Khaldun Bogor \\ E-mail: ${ }^{1}$ rita.oktaviani9666@gmail.com, ${ }^{2}$ retnotriwoelandari@uika-bogor.ac.id, \\ 3Onehamdani@gmail.com \\ DOI: $10.29313 /$ tjpi.v8i1.5169 \\ Accepted: September 26th, 2019. Approved: October 10th, 2019. Published: October 14th, 2019
}

\begin{abstract}
This study aims to find out 1) To find out the understanding of Islam towards the ethics of dressing class XI students in MAN 1 Bogor Regency 2) To find out the ethics of dressing class XI students in MAN 1 Bogor Regency 3) To find out the effect of understanding the religion of Islam on the ethics of dressing class girls XI at MAN 1 Bogor Regency. The method used is quantitative. Data collection techniques with a questionnaire and sample 60 students. The data that has been obtained is then analyzed by analyzing the validity, reliability, normality and homogeneity tests after calculating the Product Moment correlation formula. The results of this study indicate that: from the hypothesis test related to the influence of understanding of Islam on dress ethics in class XI in MAN 1 Bogor District, shows that: according to calculations using the Product Moment formula the rxy value of 0.707 was obtained and consulted with the value of $r$ table at a significant level of $5 \%$ of 0.254 . Because rxy tabel $r$ table is at a significant level of $5 \%$, the results are significant. At index 0.70-0.90 which means there is a strong or high correlation between variable $X$ and variable $Y$ so that the null bypothesis $(\mathrm{Ho})$ is rejected the hypothesis $(\mathrm{Ha})$ is accepted. This means that there is a significant strong or high relationship between the understanding of Islam and the ethics of dressing in MAN 1, Bogor Regency.
\end{abstract}

Keywords: Understanding Religion; Dressed Ethics.

\begin{abstract}
Abstrak
Penelitian ini bertujuan untuk mengetabui 1) Untuk mengetabui pemahaman agama Islam terbadap etika berpakaian siswi kelas XI di MAN 1 Kabupaten Bogor 2) Untuk mengetahui etika berpakaian siswi kelas XI di MAN 1 Kabupaten Bogor 3) Untuk mengetabuipengarub pemahaman agama Islam terhadap etika berpakaian siswi kelas XI di MAN 1 Kabupaten Bogor. Metode yang digunakan adalah kuantitatif. Teknik. pengumpulan data dengan angket dan sempel siswi sebanyak 60 orang. Data yang telab diperoleh lalu dianalisis dengan analisis uji validitas, reliabilitas, normalitas dan homogenitas setelah menghitung dengan rumus korelasi Product Moment. Hasil penelitian ini menunjukan babwa: dari uji hipotesis berkaitan dengan adanya pengarub pemahaman agama Islam terhadap etika berpakaian pada kelas XI di MAN 1 Kabupaten Bogor. Menunjukan babwa: sesuai perbitungan dengan menggunakan rumus Product

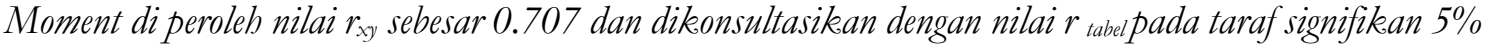
sebesar 0.254. Karena $r_{x y} \geq r_{\text {tabel }}$ pada taraf signifikan 5\% maka hasilnya signifikan. Pada indeks 0,700,90 yang berarti terdapat korelasi yang kuat atau tinggi antara variabel $X$ dan variabel $Y$ sehingga bipotesis nol (Ho) ditolak. bipotesis (Ha) diterima. Hal ini berarti ada bubungan kuat atau tinggi yang signifikan antara pemahaman agama Islam terhadap etika berpakaian di MAN 1 Kabupaten Bogor.
\end{abstract}

Kata Kunci: Pemahaman Agama; Etika Berpakaian. 


\section{PENDAHULUAN}

Agama dari bahasa dapat diikuti antara lain uraian yang diberikan Harun Nasution. Menurutnya, dalam masyarakat Indonesia selain dari kata agama, dikenal pula kata din (ديـن dari Arab dan Religi dalam bahasa Eropa. Menurutnya, agama berasal dari kata Sanskrit. Menurut satu pendapat, demikian Harun Nasution mengatakan, kata itu tersusun dari dua kata, $\mathrm{a}=$ tidak dan gam $=$ pergi, jadi agama artinya tidak pergi, tetap di tempat yaitu di warisi turun temurun (Nata, 2014).

Dari pengertian di atas dapat dipahami bahwa agama dibutuhkan untuk menyadarkan seseorang tidak dalam keadaan kacau, manusia membutuhkan agama tidak sekedar untuk kebaikan dirinya dan dihadapan sang pencipta. Melainkan juga untuk membantu dirinya dalam menghadapi berbagai macam-macam problem yang kadang-kadang tidak dipahaminya, dengan adanya agama hidup kita akan selalu terarah.

Agama merupakan salah satu perantara yang mengatur kehidupan manusia baik hubungan manusia dengan manusia maupun dengan penciptanya. Pengertian ini tampak menggambarkan salah satu fungsi agama sebagai tuntunan bagi kehidupan manusia dan agama memberikan pedoman bagi manusia untuk berhubungan dengan sang pencipta dan memberikan perilaku yang berpola dan bermasyarakat. Agama Islam adalah agama kemanusiaan, menempatkan manusia pada tingkatan yang mulia, Islam tetap mengakui tabiat asli yang terkandung dalam jiwa manusia, agama saat ini memang kurang sangat diperhatikan, khususnya kalangan para peserta didik di lingkungan sekolah, pemahaman sehari-hari, maka disinilah perlunya bagi kalangan siswa untuk memahami agama Islam secara mendalam, Islam bukan hanya mengatur dengan Allah SWT, tetapi juga mengatur hubungan antara sesama manusia, bahkan Islam mengatur seluruh insan termasuk masalah berpakaian.

Pakaian atau albisah adalah bentuk jamak dari libas yaitu apa yang dikenakan oleh manusia untuk menutup anggota tubuhnya, keseluruhan atau sebagiannya. untuk melindungi dirinya dari panas dan bahaya, seperti gamis pakaian dan selendang dan inti dari berpakaian adalah menutupi. karena Islam mewajibkan umatnya untuk menutup aurat dan seharusnyanya suatu pakaian itu yang baik, indah, bersih dan sopan dan berpakaian termasuk nikmat Allah yang diberikan kepada hambanya (Thawilah, 2014).

Sebagaimana Allah menjelaskan di dalam firmannya QS. Al-Araf ayat 26 dan 27 yang berbunyi:

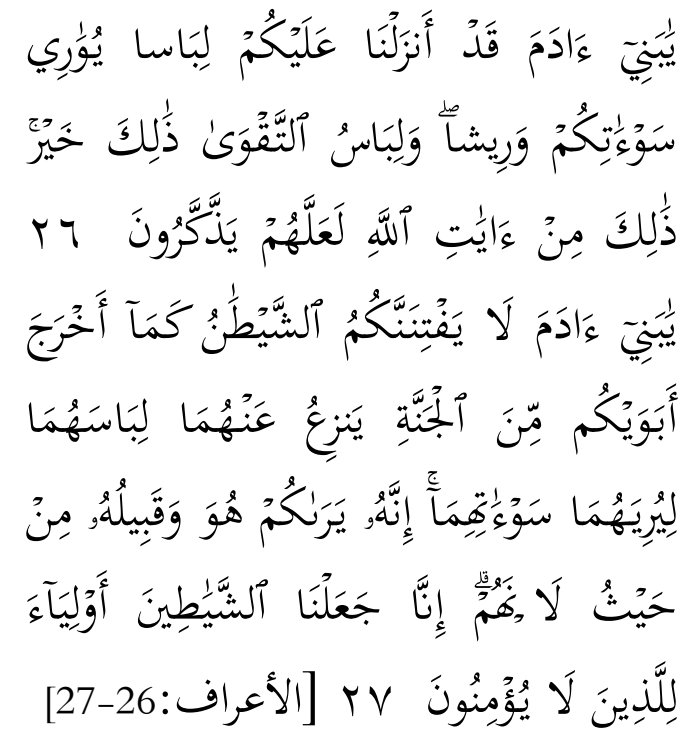

Hai anak. Adam! Sesunggubnya kami telah menurunkan pakaian kepadamu pakaian untuk menutup auratmu dan pakaian indah untuk perbiasan dan pakaian takwa, itulah yang lebih baik. Demikianlah sebagian tanda-tanda kekuasaan Allah, mudah-mudahan mereka ingat, Hai anak. Adam! Janganlah sampai kamu tertipu oleb setan sebagaimana halnya dia (setan) telah mengeluarkan ibu bapakmu dari surga, dengan menanggalkan pakaian keduanya untuke memperlihatkean aurat keduanya. Sesunggubnya dia dan pengikutnya dapat melihat kamu dari suatu tempat yang kamu tidak bisa melihat mereka. Sesunggubnya kami telah menjadikan setan-setan itu pemimpin bagi orang-orang yang tidak beriman.

Al-wasith terdapat dalam tafsirnya menjelaskan bahwa ayat tersebut menjelaskan bahwa disampaikan kepada 
seluruh umat manusia pada masa Nabi SAW, yang dimaksud dari seruan ini adalah kaum Quraisy dan bangsa Arab lainnya yang ketika itu bertelanjang saat menunaikan thawaf mengelilingi Ka'bah. Dalam ayat ini diungkap mengenai karunia dari Allah SWT bagi hamba-hambanya berupa pakaian yang diberikan kepada mereka untuk menutupi aurat (Az-Zuhaili, 2012).

\section{METODOLOGI PENELITIAN}

Penelitian ini dilaksanakan di Sekolah MAN 1 Kabupaten Bogor. Penelitian dilaksanakan pada bulan Juli 2019 periode Semester Genap 2019/2020. Subjek dalam penelitian ini adalah siswi MAN 1 Kabupaten Bogor.

Metode penelitian ini yang digunakan adalah penelitian kuantitatif. Teknik yang digunakan dalam pengumpulan data melalui angket, penelitian kuantitatif adalah terbanyak yang dituntut menggunakan angka, mulai dari pengumpulan data penafisran terhadap sata tersebut serta penampilan dari hasilnya. Dari pemahaman akan kesimpulan penelitian ini akan lebih baik apabila juga disertai dengan tabel, grafik, bagan, gambar, dan tampilan lain (Arikunto, 2014).

Teknik yang digunakan dalam pengumpulan data penelitian adalah kuesioner data dari penyebaran angket yang diisi oleh siswi yang mendukung penelitian ini.

Teknik analisis data menggunakan teknik kuantitatif menggunakan statistik. Untuk mengolah data yang diperoleh, penulis menganalisis menggunakan program SPSS versi 25 untuk sistem operasi windows.

\section{PEMBAHASAN DAN HASIL PENELITIAN}

\footnotetext{
Pemahaman adalah kemampuan dalam mengartikan, menafsirkan, menterjemahkan atau menyatakan sesuatu dengan caranya sendiri tentang pengetahuan yang pernah diterima. Pemahaman berasal
}

dari kata paham yang artinya mengerti benar dalam suatu hal, sedangkan menurut Anas Sudjiono pemahaman adalah kemampuan seseorang untuk mengerti sesuatu dan setelah sesuatu itu diketahui dan diingat. Agama Islam adalah satu-satunya agama yang di akui di sisi Allah SWT. Ajaran dan ketentuan-nya yaitu Al-qur'an dan sunnah, sehingga beruntunglah bagi mereka yang telah menjadi pengikutnya kemudian dapat pula melaksanakan dan mengamalkan ajaran Islam secara baik dan benar. Islam berarti suatu nama bagi agama yang ajaran ajarannya di wahyukan kepada manusia melalui rasul. Agama Islam adalah ajaran-ajaran yang di wahyukan.

Allah kepada masyarakat melalui Nabi Muhammad SAW sebagai Rasul Allah SWT. Sebagai pakaian khusus orang kafir ahli drimmah sedangkan orang Islam memakai pakaian yang berwarna lainnya, seperti coklat dan abu-abu. Namun, yang sesuai dengan sunnah Nabi adalah sebaliknya yaitu pakaian putih bagi muslim. Begitu pula mengenai perbedaan bentuk rambut mereka dan sebagainya. Hal-hal yang terkait dengan pakaian laki-laki dan pakaian wanita pun demikian. Tujuannya bukan sekedar membedakan, namun harus memperhatikan aspek menutupi dan melindungi tubuh wanita. Begitu pula sebaliknya, bukan hanya sekedar untuk menutupi dan melindungi tubuh wanita, tetapi juga harus membedakan antara keduanya (Albani, 2014)

Belakangan ini, hidup religious dengan menggunakan simbil-simbol agama seperti jilbab melanda masyarakat modern, khususnya mayarakat perkotaan, maraknya penggunaan jilbab di kalangan muslimah, bisa jadi karena ada kesadaran beragama. Ini tentunya bukan merupakan satu-satunya faktor. Ada wanita yang memakai jilbab tetapi apa yang dipakainya atau perilakunya tidak mencerminkan seorang yang berjilbab, dan tidak sejalan dengan tuntutan agama dan budaya masyakarat Islam (Wijayanti, 2017).

Berbusana sebagai bagian dari keadaban manusia memiliki tujuan, baik yang bersifat spesifik maupun general. Berbusana 
berarti mengenakan pakaian yang orientasinya pada nilai keindahan yang disesuaikan dengan situasi dan kondisi pengguna (Alifudin, 2014)

Etika berpakaian Menurut Pandangan Islam adalah menutup aurat dari pandangan orang lain hukumnya wajib. Menurut jumhur ulama, menutup aurat merupakan syarat keabsahan shalat, sedangkan menurut sebagian Malikiyah termasuk fardhu shalat. Aurat wajib ditutup dengan pakaian yang dapat menghalangi kulit dari pandangan, baik terbuat dari kain, kulit, kertas, tumbuhtumbuhan, maupun bahan baku lain yang bisa digunakan sebagai penutup (Thawilah, 2014).

Pakaian yang paling utama adalah menutup aurat, sekaligus sebagai perhiasan dan memperindah jasmani manusia. Agama Islam memerintahkan kepada setiap manusia untuk berpakaian yang bersih, baik, bagus dan rapih.

Menurut Ibnu Qaththan mengemukakan: wanita boleh menampakkan wajah dan telapak tangannya. Namun, dikecualikan darinya apa-apa yang tidak boleh ditampakkannya dengan tujuan bersolek dan menamppakkan kecantikannya, maka perbuatan itu menjadi haram. Oleh karena itu, perhiasan yang boleh ditamppakkan wanita hanyalah yang memang biasa tampak tatkala bepergian atau bekerja. Wanita wajib menutup bagian tubuh tatkala beraktivitas sebagaimana ia pun wajib menutupinya saat tidak melakukan apa-apa (Albani, 2017).

Berdasarkan uraian di atas, penelitian ini bertujuan untuk mengetahui pengaruh pemahaman agama Islam terhadap etika berpakaian di MAN 1 Kabupaten Bogor.

Populasi yang digunakan dalam penelitian ini hanya mengambil di kelas XI dengan jumlah 12 kelas di MAN 1 kabupaten Bogor dengan jumlah siswi 582 orang. Teknik pengambilan sampel dalam penelitian ini adalah menggunakan teknik sampel acak atau random. Sampel dalam penelitian ini berjumlah 60 orang yang terbagi dalam 12 kelas. Adapun untuk teknik pengambilan data yang digunakan adalah kuesioner (Angket).

Pada penelitian ini menggunakan instrumen penelitian yaitu kuesioner dan skala likert. Sedangkan untuk syarat uji analisis penelitian menggunakan rumus validitas, relibilitas, normalitas dan homogenitas. Sedangkan untuk menganalisis data digunakan rumus pearson product moment perhitungan rumus diatas diolah menggunakan SPSS 25 dan kemudian di lanjutkan dengan uji ananlisis data.

Responden dalam penelitian ini yaitu siswi kelas XI di MAN 1 kabupaten Bogor. Dalam pengambilan sampel menggunakan teknik Random Sampling yang terdiri dari siwi kelas X1 sebanyak 60 Siswa. Untuk menguji apakah alat ukur atau instrumen yang digunakan memenuhi syarat-syarat alat ukur yang baik. Sehingga menghasilkan data yang sesuai dengan apa yang diukur, maka terlebih dahulu dilakukan pengujian data melalui validitas, reliabilitas, normalitas dan homogenitas.

Validitas adalah suatu ukuran yang menujukkan tingkat-tingkat kevalidan atau kesahihan sesuatu instrumen. Perhitungan uji validitas menggunakan bantuan SPSS 25. Hasil uji validitas instrumen dirangkum dalam tabel berikut:

\section{Tabel 1. Hasil Uji Validitas (Variabel X dan Variabel Y)}

\begin{tabular}{ccccc}
\hline Variabel & $\begin{array}{c}\text { Jumla } \\
\mathbf{h} \\
\text { Item }\end{array}$ & $\begin{array}{c}\text { Jumla } \\
\mathbf{h} \\
\text { Gugur } \\
\text { Item }\end{array}$ & $\begin{array}{c}\text { Nomo } \\
\text { r Item } \\
\text { Gugur }\end{array}$ & $\begin{array}{c}\text { Jumla } \\
\mathbf{h} \\
\text { Item } \\
\text { Valid }\end{array}$ \\
\hline $\begin{array}{c}\text { Pemaham } \\
\text { an Agama }\end{array}$ & 30 & 1 & 2 & 29 \\
$\begin{array}{c}\text { Islam dan } \\
\text { etika }\end{array}$ & & & & \\
berpakaian & & & & \\
\hline
\end{tabular}

Hasil Validitas yang telah diteliti oleh penulis menunjukan bahwa item yang berjumlah 30 Pernyataan dikatakan Valid. 
Tabel 2. Hasil Uji Reliabilitas Variabel $\mathrm{X}$ dan Variabel Y

\begin{tabular}{lccc}
\hline Variable & $\begin{array}{l}\text { Cronbach's } \\
\text { Alpha }\end{array}$ & $\begin{array}{l}\text { N of } \\
\text { Items }\end{array}$ & Information \\
\hline $\begin{array}{l}\text { Pemahaman } \\
\text { Agama } \\
\text { Islam }\end{array}$ & 0,856 & 15 & Reliabel \\
\hline $\begin{array}{l}\text { Etika } \\
\text { Berpakaian }\end{array}$ & 0,840 & 15 & Reliable \\
\hline
\end{tabular}

Pada penelitian ini uji normalitas menggunakan Uji Kolmogorov-Smirnov Z. Hasil perhitungan uji normalitas residual diperoleh hasil nilai tes statistik kolmogorov-smirnov $Z$ adalah 0,916 dengan nilai signifikansi sebesar 0,372> dari 0.05, sehingga dapat disimpulkan data yang digunakan berdistribusi.

Tabel 3. Hasil Uji Normalitas Variabel $X$ dan Variabel Y

\begin{tabular}{|c|c|c|}
\hline \multicolumn{3}{|c|}{ One-Sample Kolmogorov-Smirnov Test } \\
\hline \multicolumn{3}{|r|}{$\begin{array}{l}\text { Unstandar } \\
\text { dized } \\
\text { Residual }\end{array}$} \\
\hline $\mathbf{N}$ & & 60 \\
\hline \multirow{2}{*}{$\begin{array}{l}\text { Normal } \\
\text { Parameters }\end{array}$} & Mean & .0000000 \\
\hline & $\begin{array}{l}\text { Std. } \\
\text { Deviation }\end{array}$ & 3.70183936 \\
\hline \multirow{3}{*}{$\begin{array}{l}\text { Most } \\
\text { Extreme } \\
\text { Differences }\end{array}$} & Absolute & .077 \\
\hline & Positive & .069 \\
\hline & Negative & -.077 \\
\hline \multicolumn{2}{|l|}{ Test Statistic } & .077 \\
\hline \multicolumn{2}{|c|}{ Asymp. Sig. (2-tailed) } & $.200^{\mathrm{c}, \mathrm{d}}$ \\
\hline \multicolumn{3}{|c|}{ a. Test distribution is Normal. } \\
\hline \multicolumn{3}{|c|}{ b. Calculated from data. } \\
\hline \multicolumn{3}{|c|}{ c. Lilliefors Significance Correction. } \\
\hline \multicolumn{3}{|c|}{$\begin{array}{l}\text { d. This is a lower bound of the true } \\
\text { significance. }\end{array}$} \\
\hline
\end{tabular}

Dari tabel di atas menunjukan perolehan hasil uji normalitas dengan nilai 0,200. Data dikatakan normal karena sig. (2tailed) lebih tinggi daripada 0,05. Hal ini menunjukan bahwa $\mathrm{Ha}$ diterima dan $\mathrm{Ho}$ ditolak dan hasil data tersebut adalah normal.
Uji homogenitas digunakan untuk mengetahui varian populasi data apakah antara dua kelompok atau lebih data memiliki varian yang sama atau berbeda. Kriteria pengujian sebagai berikut:

\section{Tabel 4. Hasil Uji Homogenitas}

\begin{tabular}{cccc}
\hline $\begin{array}{c}\text { Levene } \\
\text { Statistic }\end{array}$ & Df1 & df2 & Sig. \\
\hline $\mathbf{1 . 6 5 4}$ & 1 & 118 & 0.201 \\
\hline
\end{tabular}

\section{Berdasarkan tabel output "test of} Homogeneeity of Variances" di atas diketahui nilai signifikansi (sig.) variabel pemahaman agama Islam dan variabel etika berpakaian adalah sebesar 0,201. Karena nilai sig. 0,201 $>0,05$, maka sebagaimana dasar pengambilan keputusan dalam uji homogenitas di atas, dapat disimpulkan bahwa varian data hasil pemahaman agama Islam dan etika berpakaian adalah sama atau homogen.

Pada penelitian pemahaman agama Islam terhadap etika berpakaian di MAN 1 kabupaten Bogor. Peneliti menggunakan rumus korelasi product moment untuk mengetahui tingkat korelasi antara (variabel $\mathrm{X}$ ) dengan (variabel $\mathrm{Y}$ ),

dijelaskan dalam tabel di bawah ini:

Tabel 5. Hasil Uji korelasi 


\begin{tabular}{|c|c|c|c|}
\hline \multicolumn{4}{|c|}{ Correlations } \\
\hline & & $\begin{array}{c}\text { pemahaman_ } \\
\text { agama_isla } \\
\mathrm{m}\end{array}$ & $\begin{array}{c}\text { etika_ }_{-} \\
\text {berpaka } \\
\quad \text { ian }\end{array}$ \\
\hline \multirow[t]{3}{*}{$\begin{array}{l}\text { Pemahaman_aga } \\
\text { ma_ } \\
\text { [slam }\end{array}$} & $\begin{array}{l}\text { ?earson } \\
\text { Correlatio } \\
\text { n }\end{array}$ & 1 & $.707^{* *}$ \\
\hline & $\begin{array}{l}\text { ig. }(2- \\
\text { tailed) }\end{array}$ & & .000 \\
\hline & $N$ & 60 & 60 \\
\hline \multirow[t]{3}{*}{ Etika_berpakaian } & $\begin{array}{l}\text { ?earson } \\
\text { Correlatio } \\
\mathrm{n}\end{array}$ & $.707^{* *}$ & 1 \\
\hline & $\begin{array}{l}\text { jig. }(2- \\
\text { tailed) }\end{array}$ & .000 & \\
\hline & $N$ & 60 & 60 \\
\hline
\end{tabular}

Berdasarkan hasil perhitungan di atas, dapat dilihat antara variabel $\mathrm{x}$ dan variabel y memiliki koefisen korelasi sebesar 0,707 atau $0,707 \geq \alpha=0,05$. Jika dilihat dari interpretasinya ternyata terletak antara 0,70 - 0,90. Dari data tersebut, dapat diketahui.

Dengan demikian dapat disimpulkan bahwa pengaruh pemahaman agama Islam terhadap etika berpakaian di MAN 1 Kabupaten Bogor Untuk hasil interpretasi nilai yang lebih teliti, maka peneliti uji hipotesis yang telah di tetapkan dengan membandingkan besarnya $r_{x y}$ dengan besar $\mathrm{r}_{\text {tabel }}$ dengan melihat nukilan tabel nilai Koefisien Korelasi. Product moment dari correlation pearson untuk berbagi df.

Langkah pertama, menghitung dfnya terlebih dahulu. $\mathrm{Df}=\mathrm{N}-\mathrm{nr}=60-2=$ 58. Oleh karena itu peneliti menggunakan $\mathrm{df}$ sebesar 60. Dengan df sebesar 60 diperoleh $r_{\text {tabel }} 0,254$. Ternyata $r_{x y}$ lebih besar dari pada $r_{\text {tabel }}$ pada taraf signifikan, sehingga hipotesis nol (Ho) ditolak dan hipotesis alternatif $(\mathrm{Ha})$ diterima.

Berdasarkan penjelasan dari hasil penelitian di atas dapat diperoleh informasi, pemahaman agama Islam terhadap etika berpakaian di MAN 1 kabupaten Bogor. Hal ini membuktikan bahwa terdapat pengaruh signifikan yang kuat atau tinggi pemahaman agama Islam terhadap etika berpakaian. Di mana hasil angket yang telah disebarkan kepada siswa dan siswi kelas XI dengan jumlah 60 responden. Setelah melalui tahap perhitungan, maka diperoleh $r_{x y}$ sebesar 0,707 .

\section{KESIMPULAN}

Berdasarkan hasil penelitian
kesimpulan bahwa pertama, setelah menghitung dengan correlation pearson didapat perolehan $\mathrm{r}_{\mathrm{xy}}$ sebesar 0,707. Pada indeks 0,70-0,90 yang berarti terdapat pengaruh signifikan yang kuat atau tinggi antara variabel $\mathrm{X}$ dan Variabel Y. Ternyata $\mathrm{r}_{\mathrm{xy}} \geq$ sebesar 0,707 sehingga hipotesis nol (Ho) ditolak dan hipotesis $(\mathrm{Ha})$ diterima. Hal ini berarti ada pengaruh yang kuat atau tinggi yang signifikan antara pemahaman agama Islam (Variabel X) terhadap etika berpakaian (Variabel Y) di MAN 1 kabupaten bogor Dan kedua, terdapat pengaruh yang positif yang cukup signifikan antara Pemahaman agama Islam terhadap etika berpakaian di MAN 1 kabupaten bogor.

Bahwa dapat disimpulkan pemahaman agama Islam terhadap etika berpakaian di MAN 1 kabupaten bogor terdapat korelasi yang signifikan. Seharusnya dengan pahamnya agama, seharusnya dapat diaplikasikan dalam kehidupan sehari-hari karena itu salah satu mencerminkan kepribadian muslim yang baik dan merupakan salah satu akhlak yang baik.

Bahwa pakaian sebagai penutup aurat, pelindung tubuh. Hal ini sudah jelas bahwa agama Islam sudah menentukan bagaimana cara berpakaian dengan baik dan benar. Sebagai Wanita muslimah diwajibkan mengenakan hijab yang sesuai dengan ketentuan syariat sesuai saat keluar dari rumah yaitu pakaian Islami. 


\section{DAFTAR PUSTAKA}

Al-Albani, Nashiruddin Muhammad. (2017). Kriteria Busana Muslimah. Jakarta: pustaka Imam Asy-Syafi'i.

Alifuddin. (2014). Etika Berbusana Dalam Perspektif Agama dan Budaya. Jurnal Shautut Tarbiyyah. Vol 1, No 1.

Arikunto, Suharsimi. (2014). Prosedur Penelitian Suatu Pendekatan Praktik. Jakarta: Rineka Cipta.

Az-Zuhaili, Wahbah. (2012). Tafsir al-W asith. Jilid 1. Jakarta: Gema Insani.

Habibah, Syarifah. (2014). Sopan Santun Berpakaian dalam Islam. Jurnal Pesona Dasar. Vol 2, No 3.

Nata, Abudin. (2014). Metode Studi Islam. Jakarta: PT Grafindo Persada.

Thawilah, Syaikh Abdul Wahab Absussalam. (2014). Adab Berpakaian dan Berbias. Jakarta: Pustaka Al-Kautsar.

Wijayanti, Ratna. (2017). Jilbab Merupakan Etika Berbusana Muslimah dalam Perspektif Islam. Jurnal Studi Islam. Vol.XII. No 2. 